\title{
Management and Ecological Note
}

\section{Re-establishment of the North Sea houting in the River Rhine}

\author{
J. BORCHERDING \& M. HEYNEN \\ University of Cologne Zoological Institute, General Ecology and Limnology, Research Station Grietherbusch, Rees-Grietherbusch, \\ Germany
}

\author{
T. JÄGER-KLEINICKE \\ Radebrook 3 A, Kiel, Germany
}

H. V. WINTER

IMARES, Wageningen UR, IJmuiden, The Netherlands

\author{
R. ECKMANN \\ Limnological Institute, University of Konstanz, Konstanz, Germany
}

\begin{abstract}
The anadromous fish species North Sea houting, Coregonus oxyrinchus (L.), became extinct in the River Rhine (Kranenbarg et al. 2002) and many other rivers draining to the North Sea in the 1940s (Lelek 1987). The cause was believed to be a combination of overfishing, poor water quality, habitat loss and fragmentation and barriers hampering upstream migrations (De Groot \& Nijssen 1997). Since the 1980s, water quality in the River Rhine has greatly improved, many migration barriers were facilitated with fishways (De Leeuw et al. 2005) and no commercial fisheries on houting existed after its extinction. Thus, a large part of the possible causes for extinction were mitigated. Given the small size and isolation from the only remaining houting population in Denmark, it was decided to reintroduce houting in the German section of the River Rhine (cf. Hodder \& Bullock 1997). Descendants of the last known reproducing population

Correspondence: Jost Borcherding, University of Cologne Zoological Institute, General Ecology and Limnology, Research Station Grietherbusch, D.46459 Rees-Grietherbusch, Germany (e-mail: jost.borcherding@uni-koeln.de)
\end{abstract}

of houting from the Danish River Vidå (Hansen et al. 2006) were the donor population for the Rhine re-introduction programme that started in 1996. Approximately 1.9 million juvenile houting were stocked at two locations in the Lower Rhine, up to 2005. After stocking, the fish drifted/migrated downstream towards the Rhine delta (Borcherding et al. 2006). At present, two of the three North Sea outlets of the River Rhine are closed by dams with discharge sluices (De Leeuw et al. 2005). Increasing catches of adult houting in Lake IJsselmeer, one of the two closed off former estuaries of the River Rhine (De Leeuw et al. 2005), raised the question whether these fish originated from stocking or natural reproduction. Therefore, a mark-recapture experiment was conducted in 2006, in which all houting embryos were stained with Alizarin (Eckmann 2003) before being stocked into the Lower Rhine. Otolith analysis of young-of-the-year (YOY) houting caught in the lower sections of the River Rhine should then allow identification of their origin, i.e. from stocking or from natural reproduction.

Mature houting were caught in the River Treene in northern Germany (November/December 2005). Egg 
fertilisation was carried out at a hatchery at Lake Kellersee, where eggs were incubated in zoug-jars $(50 \mathrm{~L})$ using lake water, each containing approximately 1 million houting eggs. One of these zoug-jars was connected to a recirculation system set up in February 2006. The labelling solution, made up of $1 \mathrm{~g} \mathrm{~L}^{-1}$ Tris-buffer and $1 \mathrm{~g} \mathrm{~L}^{-1}$ Alizarin Red S monohydrate (Sigma-Aldrich, Taufkirchen, Germany) dissolved in de-ionised water (temperature $1-5^{\circ} \mathrm{C}$ ), was added to the recirculation system, but with the zoug-jar isolated. When the $\mathrm{pH}$ stabilised (adjusted to 8-8.5 with $\mathrm{HCl} 25 \%$, Eckmann et al. 2007), the zoug-jar was re-incorporated in the recirculation system for $24 \mathrm{~h}$.

After hatching in mid April, houting larvae were reared in net cages in Lake Kellersee. Mortality of larvae stained with alizarin did not differ from control batches. Larvae grew about $25-35 \mathrm{~mm}$ total length $\left(L_{\mathrm{T}}\right)$ until mid May, when 400000 marked juvenile houting were stocked into the Lower Rhine and the River Lippe (Borcherding et al. 2006).

The success of the alizarin marking was evaluated against a control batch of marked houting that was retained until June; these grew up to about $60 \mathrm{~mm} L_{\mathrm{T}}$. Young-of-the-year houting were caught either in Lake IJsselmeer near the Afsluitdijk (catch date - 21 June to 25 July $2006 ; L_{\mathrm{T}}: 62-120 \mathrm{~mm}$; in the fyke net monitoring programme - Zeldzame vissen in het IJsselmeergebied; ter Hofstede \& van Willingen 2001), or with an anchored stow net in the lower River Rhine near the city of Rees (Rhine-km 843, catch date - August to October $2006 ; L_{\mathrm{T}}: 97-140 \mathrm{~mm}$ ).

Otoliths were embedded in epoxy resin and ground to the midplane, so that the otolith primordia were exposed at the surface. The otoliths were polished with aluminium oxide and then checked for alizarin marks with an epifluorescent microscope (546 nm excitation wavelength) (Eckmann 2003). The otoliths of 23 individuals of the control group all had a clear alizarin mark at the nucleus, confirming 100\% labelling success, which is in accordance with Eckmann et al. (2007).

From 55 YOY houting caught in the summer 2006 in Lake IJsselmeer, two individuals $(3.6 \%)$ had an alizarin mark at the centre of their otoliths (catch date -22 July $2006 ; L_{\mathrm{T}}: 113 \mathrm{~mm}$; catch date -24 July 2006 ; $L_{\mathrm{T}}: 94 \mathrm{~mm}$ ). None of the four individuals caught in the Lower Rhine had an alizarin mark. These results suggest that the majority of YOY houting in 2006 originated from natural reproduction, indicating the presence of a self-sustaining population. Thus, the re-introduction programme of North Sea houting in the Rhine system can be considered a success, according to the definition of IUCN (1998), and further stocking appears to be unnecessary (Seddon 1999; Fischer \& Lindenmayer 2000).

Other studies on the migration of houting further support re-establishment and show that this species uses the whole Lower Rhine, the Rhine delta and marine habitats as feeding grounds (Winter et al. 2008). Scale transects of $\mathrm{Sr}^{88}: \mathrm{Ca}^{44}$ ratios found only $\approx 10 \%$ of adult houting caught in Lake IJsselmeer in 2002 reached the sea as small juveniles, while the majority either lived exclusively in fresh water (72\%) or migrated to the marine environment later in life (18\%) (Borcherding et al. 2008). These results are in accordance with suggestions of Kranenbarg et al. (2002) that at present the riverine and estuarine waters in the Netherlands function as an important feeding habitat for the species.

These results provide evidence that houting has successfully re-established in the River Rhine. Although the present situation, with dams separating Lake IJsselmeer from the Wadden Sea and Haringvliet from the North Sea, still considerably deviates from the historical situation with open estuaries, houting appears to have suitable habitats available to re-establish. However, the low number of juveniles directly migrating to sea (Borcherding et al. 2008) suggest that connectivity and saline gradients at the dams should be restored (Kranenbarg et al. 2002), as the populations should be free-ranging in the wild (IUCN 1998).

\section{References}

Borcherding J., Pickhardt C., Winter H.V. \& Becker J.S. (2008) Migration history of North Sea houting (Coregonus oxyrinchus L.) caught in Lake IJsselmeer (The Netherlands) inferred from scale transects of ${ }^{88} \mathrm{Sr}:{ }^{44} \mathrm{Ca}$ ratios. Aquatic Sciences 70, 47-56.

Borcherding J., Scharbert A. \& Urbatzka R. (2006) Timing of downstream migration and food uptake of juvenile North Sea houting stocked in the Lower Rhine and the Lippe (Germany). Journal of Fish Biology 68, 1271-1286.

De Groot S.J. \& Nijssen H. (1997) The North Sea houting, Coregonus oxyrinchus, back in the Netherlands (Pisces, Salmoniformes, Salmonidae). Bulletin Zoölogisch Museum, Universiteit van Amsterdam 16, 21-24.

De Leeuw J.J., Buijse A.D., Grift R.E. \& Winter H.V. (2005) Management and monitoring of the return of riverine fish species following rehabilitation of Dutch rivers. Archiv fïr Hydrobiologie 155, 391-491.

Eckmann R. (2003) Alizarin marking of whitefish, Coregonus lavaretus otoliths during egg incubation. Fisheries Management and Ecology 10, 233-239.

Eckmann R., Kugler M. \& Ruhle C. (2007) Evaluating the success of large-scale whitefish stocking at Lake 
Constance. Archiv für Hydrobiologie, Special Issues Advances in Limnology 60, 361-368.

Fischer J. \& Lindenmayer D.B. (2000) An assessment of the published results of animal relocations. Biological Conservation 96, 1-11.

Hansen M.M., Nielsen E.E. \& Mensberg K.L.D. (2006) Underwater but not out of sight: genetic monitoring of effective population size in the endangered North Sea houting (Coregonus oxyrhynchus). Canadian Journal of Fisheries and Aquatic Sciences 63, 780-787.

Hodder K.H. \& Bullock J.M. (1997) Translocations of native species in the UK: implications for biodiversity. Journal of Applied Ecology 34, 547-565.

IUCN (1998) Guidelines for Re-introductions. Cambridge: Prepared by the IUCN/SSC Re-introduction Specialist Group, $10 \mathrm{pp}$.
Kranenbarg J., Winter H.V. \& Backx J.J.G.M. (2002) Recent increase of North Sea houting and prospects for recolonization in the Netherlands. Journal of Fish Biology 61(Suppl. A), 251-253.

Lelek A. (1987) The Freshwater Fishes of Europe - Threatened Fishes of Europe. Wiesbaden: AULA Verlag, 343 pp.

Seddon P.J. (1999) Persistence without intervention: assessing success in wildlife reintroductions. Trends in Ecology \& Evolution 14, 503.

ter Hofstede R. \& van Willingen J.A. (2001) Zeldzame vissen in het IJsselmeergebied - Jaarrapport 2000. RIVO Rapport Nummer C038/01, Lelystad, 41 pp.

Winter H.V., De Leeuw J.J. \& Bosveld J. (2008) Houting in het IJsselmeergebied. Een uitgestorven vis terug? Wageningen IMARES Rapportnummer C084/08, IJmuiden, 31 pp. 